\title{
The travel blogger as digital nomad: (Re-)imagining workplace performances of digital nomadism within travel blogging work
}

\section{Nina Willment ${ }^{1}$ (D)}

Received: 7 October 2019 / Revised: 28 February 2020 / Accepted: 16 March 2020 /

Published online: 30 March 2020

(C) The Author(s) 2020

\begin{abstract}
Through analysis of empirical fieldwork conducted with British travel bloggers, this paper details a novel and significant investigation into the nuances of selfpresentation and performances inherent in travel blogging work, through the lens of digital nomadism. Working with Goffman's (The presentation of self in everyday life. Penguin, London, 1959) ideas of front and back regionalisation, the paper explores the distinct ways in which digital nomadism is performed by the travel blogger. Firstly, the paper highlights how performances of digital nomadism are integral to the successful self-presentation of the travel blogger as an aspirational worker. Next, it showcases how travel bloggers use performances of digital nomadism in the strategic complication of the front and back-stage of their work, in order to demonstrate authenticity to their audience. The paper then considers how travel bloggers undertake performances of digital nomadism, explicitly within the frontstage to aid in their overall impression management of being a travel blogger. Subsequently, the paper turns to discussions of how technology becomes utilised in performances of digital nomadism which flow across the travel blogger's front and back-stage. Finally, the paper reviews how, through performances of digital nomadism, the travel blogger appropriates their own back-stage leading to issues of overwork and precarity. The paper's original contribution lies in its use of the lens of digital nomadism to enable us to explore and reimagine the workplace performances of travel bloggers. In doing so, the paper is able to speculate on the nuances and motivations implicit in these performances, digging deeper into issues of online selfpresentation, authenticity and place.
\end{abstract}

Keywords Digital nomadism · Workplace geographies · Travel bloggers · Dramaturgical performance $\cdot$ Staged authenticity

Nina Willment

Nina.Willment.2013@live.rhul.ac.uk

1 Department of Geography, Royal Holloway University of London, Egham Hill, Egham, Surrey TW20 0EX, UK 


\section{Introducing travel bloggers, place and digital nomadism}

Through communications technology, travellers can now keep in almost constant contact with friends, work and fellow travellers remaining co-present in their social, home and work life (Mascheroni 2007). Technologies such as social networking sites and blogs, are allowing individuals to shift between these multiple networks instantaneously wherever they are in the world (Paris 2012). As a result of these digital technologies and the networked connections they facilitate, new forms of multi-location work are rising. In particular, the affordance of these technologies has facilitated a huge rise in the location-independent workers termed 'digital nomads' (Muller 2016). Defined by Nash et al. (2018, p 1) as individuals who are 'pursuing employment that allows for global travel, flexibility in work hours and a departure from the traditional office environment'; digital nomadism was initially coined as a term to describe a geography of work, where the location that the work was done in did not matter.

However, increasingly research has begun to recognise the value of place as a prevailing justification in the lifestyle choice of digital nomads. Schlagwein (2017) discusses how the opportunity of experiencing different places and cultures, implicit in living a digitally nomadic lifestyle, is highly valued. This centrality of place and placed experiences critically differentiates digital nomadism from remote working. Whereas remote work may be wholly unconcerned with place, the value in experiencing different cultures and places is a motivating factor in individuals undertaking a digitally nomadic lifestyle. Moreover, Schlagwein (2017) also details the economic justifications expressed by digital nomads and how place matters in this respect. For digital nomads, the low-cost of living in certain countries can play an important role when starting up a digital business. Again, the centrality of place from an economic standpoint, highlights a key difference between digital nomadism and remote working.

One intriguing example of a digitally nomadic worker who has not yet achieved widespread academic focus is the travel blogger. The growth of social and participatory media has led to an increase in online travel writing and has resulted in publishers, authors and readers all now becoming players in the production of travel information. Blaer et al. (2020, p 2) note how travel blogs in particular, have proliferated in the last 20 years, facilitating 'the rise of the modern amateur travel writer'. Puhringer and Taylor (2008, p 179) define travel blogs as 'the equivalent of personal online diaries and are made up from one or more individual entries strung together by a common theme (for example a trip itinerary)'. Travel bloggers are therefore the individuals who create and maintain these blogs. Within their travel blogs, individuals attempt to generate income through means such as paid partnerships, guest posts, sponsored posts, advertising and affiliate links. Travel bloggers may also undertake offline work related to their blog such as running 'how to blog' courses or completing speaking engagements. Many travel bloggers may also undertake gig work, typically in the form of freelance writing or copyrighting tasks, in order to supplement the income they make from blogging (Azariah 2016a). 
Travel blogging is therefore a particular form of work, where individuals see themselves as digital nomads. Yet, travel blogging is representative of a particular kind of digital nomadism. For travel bloggers, digital nomadism is an integral part of the work that they do. Travel blogging work therefore suggests that far from not mattering, place and location, and their intersections with ideas of mobility are central to the performances and practices of digital nomadism. There is an inherent need for travel bloggers to produce diverse travel content from across the globe and to perpetually share this content, whilst on the move, with their online audience. Firstly then, travel bloggers must report from a distinctive place or location and therefore the place of reporting or (touristic) experience is central to their digitally nomadic work in this regard. Secondly, the availability of a laptop and Internet access can facilitate the transformation of any place into a place of work by the travel blogger. Considerations of place are therefore extremely significant in our understanding of travel blogger's performances of digital nomadism, and therefore this paper seeks to pay attention to these two interpretations of place, highlighting how each intersects with digital nomadism in different ways. In particular, the paper seeks to use Goffman's (1959) ideas of front and back regionalisation as a framing, through which we can explore and reimagine these specific workplace performances of digital nomadism. The paper also shows how exploring the working practices of the travel blogger can enable us to dig deeper into wider themes such as self-performance, authenticity and place which are important in expanding our understandings of digital nomadism.

The paper therefore begins with three contextual sections, which aim to position the paper in relation to current literatures and to demonstrate its original contribution to discussions of digital nomadism. The first section contextualises the work of travel blogging in relation to wider industrial changes and the digitalisation of travel writing. The second contextual section discusses the paper in relation to other studies which have used Goffman's (1959) theory to understand self-presentation in the online world. The final contextual section situates the paper in the midst of literatures which explore themes of self-presentation and highlights the paper's role in discussing the relationship between travel blogging, workplace performances and authenticity. These contextual sections are followed by a brief methodology section. The paper then moves to the analytical section which builds on empirical data to explore how performances of digital nomadism are enacted in the self-presentation of travel bloggers.

\section{Exploring digitalism and travel writing}

Within the years since 1995, we have witnessed a rapid transformation in the journalism industry particularly among Western societies (Hanusch 2015). This era of transformation has subsequently been described as a moment of 'crisis' by some commentators (Franklin 2012, p 665). Hanusch (2015) worked with Australian journalists to try to understand how these workers experienced the cultural, economic and technological changes facing their industry. Firstly, he found that new technologies (particularly social media) were shifting traditional definitions of journalism. Audiences were becoming increasingly involved in practices of journalism 
themselves, creating and re-crafting news content. Secondly, from an economic perspective, established business models of journalism had moved online, creating increasingly precarious job situations for journalists. Changes in technology, particularly the evolution of the social media era, have facilitated an environment which has forced travel writers in particular, to construct new meanings and purposes for their work (Blaer et al. 2020). Pirolli (2017) discusses how this moment of change facilitated by the proliferation of user generated travel content, has resulted in an identity crisis for established travel journalists. Travel journalists are now actively seeking to differentiate themselves from other travel content creators, such as bloggers, through the development of a specific, occupational ideology. Focusing on the destination of Paris, Pirolli (2017) found that travel journalists sought to assert themselves as distinct from bloggers and other non-professionals. One way in which journalists attempted to differentiate themselves was in relation to brand loyalty. Journalists are under editorial limitations and therefore demonstrate a strong affliction with the brands of the publication they are working for.

In the context of employment and jobs, Rosenkranz (2019) notes how a reduction in the demand for print travel writing has resulted in a shift in contracting, from assignment-contracts to speculative short-term, project-based contracts. This shift in contracting is resulting in travel writing freelances having to personally accept all of the risks of production; financing their own travel and writing costs. Blaer et al. (2020) therefore note the need for travel writers to 'brace themselves' for the increasingly dynamic working environment in which they are situated. In particular, the authors note the need for continual adaptation in this increasingly fluid and evolving digital, travel writing era. Within the midst of a travel journalist field plagued by folding publications and reductions in pay for travel freelancers, Rosenkranz (2016) argues that travel journalists have had to have an entrepreneurial response. Travel journalists have had to transform themselves into travel personalities, presenting themselves in such a way they are able to build both an audience and a personal brand which they can subsequently monetise. In focusing exclusively on travel bloggers, this study offers new insights into these specific examples of travel writers who have emerged in the new digital age. The paper also makes a contribution by highlighting how themes of industrial precarity and audience engagement influence and mould the specific performances of digital nomadism travel bloggers undertake (Blaer et al. 2020; Rosenkranz 2016).

\section{Exploring travel blogging and self-presentation}

In thinking specifically about travel blogging, Azariah (2016a) argues that their simultaneous public, yet personal, quality means that blogs can be understood as an important narrative of self-presentation. She notes how Goffman's notion of social interaction as a staged performance is a useful metaphor for understanding and engaging with how individuals position themselves and interact with others online. In order to explain everyday social interactions and behaviours, Goffman (1959) developed his dramaturgical perspective which characterised social life as a 'performance'. Throughout the performance of daily life, individuals are characterised 
as 'actors' who play different roles and display different types of behaviours, in order to present their self in different ways. In particular, Goffman uses workplaces as the examples through which he develops his discussions of social encounters and associated performances. Applying his dramaturgical metaphor to discussions of social performances, Goffman (1959) develops the concept of front and back regionalisation. Goffman (1959) uses the term 'frontstage' or 'front-region' performance to refer to the behaviour that individuals undertake when they know others are watching. As a result, frontstage behaviour is typically routinised and follows a 'script' defined and shaped by the cultural norms and expectations of this social performance. Within a front stage setting, individuals are aware of what others expect and how they may be perceived. This dictates what individuals, do, say, their mannerisms and even what they wear. In contrast, a 'backstage' or 'back-region' performance is where individuals undertake behaviour free from the constrains and expectations that dictate front-region performances. This may result in individuals changing their appearance, clothes or how they speak, act or carry themselves. This is because the back region is typically entirely private and hidden from the audience and can therefore play a vital role in protecting the worker from demands placed on them (Bolton 2005). The back-region can additionally function as a space where front-region performances can be practiced and honed.

Central also to Goffman's dramaturgical theory is the idea of 'impression management'. This is the notion that within all social situations, 'individuals attempt to control the impressions others form of them' (Leary and Kowalski 1990, p 34). One of the complexities of Goffman's account is that impression management may occur within back-regions, as well as front-regions, unless these back-regions are entirely private. This is because the impressions that individuals have of others have a direct effect on how they are perceived and treated. In this way, we can think of individuals as actors who wish to convey a certain impression to their audience (Picone 2015). These impressions are informed by what Goffman terms 'sign vehicles'. Goffman notes two different examples of sign vehicles; 'expressions given' and 'expressions given off'. Expressions given are verbal symbols which are used to express information, and which are controlled and deployed by the individual. Expressions given off are signs and symbols which the body does, but which are subsequently interpreted by others and are therefore, somewhat beyond the individuals control. Examples of expressions given off include sweating or blushing. Although Goffman's studies refer to face-to-face interactions, electronic interaction has been signalled as a natural extension to what Goffman discussed (Meyrowitz 1986).

As a result, Goffman's dramaturgical theory has subsequently been deployed in the examination of computer-mediated communications and online spaces of work, especially in relation to blogging and social media (Hogan 2010; Bullingham and Vasconcelos 2013; Orth 2016). Azariah (2016b) directly uses Goffman's theory to think about issues of self-presentation in relation to blog authorship. She notes how travel bloggers may undertake self-presentation strategies in order to position the self as a traveller, rather than as a tourist, in their blogs. She also highlights the tensions that may arise from this self-presentation in instances where the travel blog subsequently becomes translated into a published account of travel, in the form of a book or a guidebook. At this point of publication, the travel blogger is transformed 
into what Azariah (2016b, p 943) describes as a 'tourism-promoter-publisher'. If the authenticity of the blog as a travel narrative is as a result of the presentation of the self as a traveller, then this transformation to 'tourism-promoter-publisher' can destabilise both the blogs claim to authenticity and the bloggers claim to authorship.

Azariah (2012a) also argues that travel blogger's self-presentation can be extended beyond the travel blog to other author-created content such as Twitter accounts. She finds that travel bloggers use the technological conventions of Twitter as self-presentational techniques to strengthen their position as travel bloggers. For example, techniques such as 'retweeting' help to keep the presentation of the self as a travel blogger alive for the audience. This idea extends Goffman's argument that individuals use cues appropriate to social situations in order to indicate their position in relation to their audience. Although Goffman's (1959) theory has been applied to contemporary travel writers (McWha et al. 2018) and travel bloggers (Azariah 2016a; b), this study makes an original theoretical contribution by exploring the presentation of a digitally nomadic self, inherent in the workplace performances of travel bloggers. By examining the blogger through the lens of digital nomadism, the paper enhances 'our understanding of how travel writers personally experience their sense of self and the potential to construct the self-online' (McWha et al. 2018, p 17).

\section{Exploring self-presentation and authenticity}

Sweetser and Keshelashvili (2005) also build on Goffman's discussion of selfpresentation strategies in their analysis of high readership or 'A-list' blogs. They argue that much of A-list blog content attempts to provide a glimpse into a blogger's 'back-stage' (such as content showcasing the process of creating blog posts) alongside more 'front-stage' elements (such as traditional blog conversations). They found that most of the bloggers studied predominantly revealed information that would typically be considered 'back-stage' such as information about their everyday lives. This performance of 'back-stage' content could be seen as a strategy, where, through intimate self-disclosure the blogger encourages others to like and therefore engage with them. As a result, Sweetser and Keshelashvili (2005) highlight how bloggers attempt to create the impression that what the audience sees on the blog is the bloggers true 'back-stage'. In reality, this performance is deliberately crafted to be performed in public.

The deliberate performance of the back-stage in this way is reminiscent of MacCannell's (1999) seminal work on staged authenticity. MacCannell (1999) uses Goffman's concept of front and back-regions to think about ideas of staged authenticity and the structuring of performances within tourism workspaces. He notes that the ability to share in the real life of others and therefore to have an authentic, demystified experience is an overwhelming desire for tourists. However, this quest for authenticity is resulting in a proliferation of back-regions which are staged, and therefore a breakdown of the front-stage and back-stage distinction. MacCannell (1999) therefore describes how tourist settings have become settings for staged authenticity. In developing Goffman's own discussion of the sometimes-difficult separation between front and back-regions, he notes how it is extremely hard to 
distinguish between acts and authentic expressions within tourist encounters. It becomes impossible to truly know if perceived entry into a back-region is, in reality, simply entry into a front-region that has been set up for tourist consumption.

MacCannell (1999, p 99) suggests the guided tour as an example of staged authenticity, comprised of a staged back-region which resembles 'a kind of living museum' where tourists can view the inner workings of an operation. The reality of the inner workings of the operation are sustained by particular constructions known as 'mystifications'. These constructions help to convince the gazing audience of the authenticity of the guided tour. Building on Goffman's (1959) and MacCannell's (1999) work, Urry and Larsen (2011) argue that any kind of work can be transformed into an object of the tourist gaze through the construction of an artificial backstage. Individuals who may be subjected to the tourist gaze may therefore stage authenticity, in order to either protect themselves from intrusions into their true backstage or as a means to profit from this staging. In order to create these staged tourist attractions, complex processes of production are undertaken in order to ensure that regular and meaningful tourist gazes are maintained.

Yet, Wang (1999) argues that the concept of authenticity has become increasingly ambiguous since its introduction into tourism studies by MacCannell. As a result, it is important here to define how this paper addresses the notion of authenticity. In borrowing from Wang (1999), an existential definition of authenticity will therefore be used. Existential authenticity can be understood as referring to 'a potential existential state of Being that is to be activated by tourist activities' whereby individuals find their authentic (true) self' (Wang 1999, p 352). In their discussion of frontier tourists, Laing and Crouch (2011) note how these tourists gain self-discovery and attain existential authenticity (or their 'true' self) as a result of being immersed in a perilous environment. Being in this environment helps the tourist to construct and perform a new authentic sense of self. Van Nuenen (2016) argues that travel bloggers are under pressure to reconcile existential authenticity with performances of self-branding. In particular, he notes the prevalence of discourses of 'being oneself' in the marketing strategies, present within the conscious construction of a blogger's branded self. Existential authenticity functions as a powerful tool in the successful performance of the travel blogger self, where there is concurrent need 'to both become and sell yourself' (Van Nuenen 2015, p 208).

In their focus on travel writers, McWha et al. (2018) draw on Goffman's ideas of self-presentation and impression management to help understand the sense of self which is evident within travel writers written work. They found that travel writers understood their writing work as a project of existential authenticity, as travel writing is an important process through which to understand, explore and re-evaluate the sense of self. In particular, McWha et al. (2018) noted that travel writers felt the need to represent themselves in particular ways, in order to convey the message of their writing to their audiences. The process of writing itself allowed individuals to re-establish their sense of self particularly after traumatic or negative travel experiences. The authors also outlined how the digital environment is endemic of a new space in which travel writers can construct and negotiate identities of self. The authors note the sharing, commenting and re-posting practices inherent in blogging result in an extension of the authors constructed 
self, which is also more communal because the self is shared and constituted, in part, by the blogger's audience.

Duffy and Kang (2019) understand travel bloggers as individuals who stage their performances of self as a means to influence their audiences for personal, economic and/or cultural benefit. Within the spaces of the Internet, performances of the self can become used as a strategic resource to help to support claims made by the content creator to their online audience. On web pages in particular, it is to an imagined web audience who content creators orientate performances such as performances of authenticity. Subsequently, it is this imagined community who ultimately render judgements on these performances. Stylistic features of web pages such as distinctive choices of images can function as examples of resources drawn upon by content creators to aid in their performance of authenticity. This is because the presence of these features helps to induce trust between the content creator and their audience (Hine, 2000). Travel blogs are influential as they appear authentic because of the shared connection, and therefore trust, established between the blogger and the audience. In the eyes of the audience a blog is trustworthy because it is akin to talking to a friend, as the blogger's observations about a place are seemingly real experiences being discussed by an ordinary person (McCabe and Foster 2006).

Gamson (2011, p 1062) charts the rise of the ordinary within celebrity culture. In particular, he cites reality TV and the Internet (particularly, the advance of user generated content) as 'pushing ordinariness into the cultural forefront'. Online social networking and publication forms such as blogging, have given rise to the selfmade, Internet celebrity. For these individuals, self-publicity alongside revelations about the ordinary self, become a means of building an audience. It is this audience who subsequently turn the individual into a celebrity, as the audience's attention is what is considered valuable, subsequently being commodified and exchanged for an economic product. Travel bloggers are under pressure to highlight how ordinary and similar to their readers they are. As a result, the travel blogger needs to undertake a performance of amateur ordinariness, which functions as a marker of authenticity to their audience (Duffy and Kang 2019).

Yet, for travel bloggers, the act of travel is also considered valuable. The act of travel becomes valued particularly, as it is linked to examples of existential authenticity or 'finding oneself' that Wang (1999), McWha et al. (2018) and Van Nuenen (2015) discuss. At the same time as performing an ordinariness, the travel blogger must also use their blog to perform and demonstrate how exceptional they are, for instance in relation to both their professional expertise and their ability to constantly travel. Travel bloggers are therefore under pressure to simultaneously perform the exotic and the everyday. In order to perform and present these different cultural meanings, bloggers exploit their back-stage and front-stage personas (Arsel and Zhao, 2011). Travel bloggers must utilise their front-stage and back-stage in order negotiate this coincident performance of ordinary/extraordinariness and successfully maintain credibility with their audience. This paper examines the role of digital nomadism within the self-presentational performances of travel bloggers, in which they attempt to reconcile this search for an existential authenticity with a working narrative which functions, in part, as a mechanism of self-branding. In doing 
so, the paper attends to Azariah's (2016a) concern of a gap in the literature, which addresses how travel blogs relate to and engage with ideas of authenticity.

\section{Methodology}

This paper develops its broader arguments through case study descriptions of British travel bloggers from my own research as a reference point. The research is underpinned by an interpretivist philosophy. Interpretivists concentrate on the meanings and realities created by individuals in groups, and the various ways in which these individuals interpret the world (O'Donoghue, 2007). The research involved working with 19 travel bloggers who were a mix of hobbyists, professionals and those transitioning from hobbyist to professional. Hobbyist bloggers were defined as individuals for whom their blog and blogging related activities were not an economic means in their life with their blog solely serving other purposes such as staying in touch with family or friends. Professional bloggers were defined as individuals for whom the blog and blogging related activities were the sole economic means in their life. Although the blog may also serve other purposes, the blog (and associated activities relating to it) functioned as the participant's main source of income. Transitioning bloggers were defined as individuals who were increasingly situating their blog and related blogging activities as an economic means in their lives. Again, although the blog may continue to serve other non-economic purposes, the blog was viewed as becoming increasingly important as the blogger's main source of income. Additional information about the sample of research participants can be found in Appendix 1. Each participant has been assigned a 2-5 letter pseudonym alias in order to protect their identity (Tracy 2010).

Participants were recruited from a variety of Facebook groups including the 'UK Travel Bloggers' group. Participants were also recruited through speculative, direct messages sent out via email or Twitter to individuals whose contact details could be found from the first five pages of Google, under the search term 'UK Travel Blogger'. In order to be part of the study, participants had to self-identify as a travel blogger and as British. The primary interest of the research was in the working lives and workspaces of travel bloggers. The research sought to pay particular attention to travel bloggers constructions of their creative careers; the aesthetic, affective, curatorial and aspirational components of their work; and their varied workspaces. Therefore, it must be noted that the subject of digital nomadism arose as a significant theme only as the data was analysed. During data collection, participants were not asked specifically if they identified as a digital nomad. Instead, within the interviews, participants were asked how they, personally, identified with the digital nomad label. As a result, not all participants felt they identified with the digital nomadism concept or wished to discuss digital nomadism at all. The paper therefore decidedly focuses on five participants as these participants offer the richest insights into the workplace performances of digital nomadism present within travel blogging work. Following Nash et al.'s (2018) digital nomad definition, travel bloggers who still maintained a home base but who pursued location independent working which 'allows for global travel' were considered digital nomads within the study. 
The methodology for the research involved two interviews with each participant. The initial interview was semi-structured and lasted between 60 and $75 \mathrm{~min}$. The aim of this initial interview was to provide both a structured yet seemingly creative, autonomous context through which myself and participants could discuss and clarify their career in the travel blogging industry; senses of precarity and how these are navigated; the place of travel blogging work within participants' wider working lives both mentally and physically; the (transnational) heterogeneity of travel bloggers' workspaces and participants plans for the future. Following this initial interview, a second photo elicitation interview was carried out roughly 4-6 weeks after the first interview. Within photo-elicitation interviews, visual images act as a stimulus for interview discussion. Collier and Collier (1986) developed the photoelicitation method in 1957, as a means to create a longer and more detailed interview. They argued that photographs would aid in the retrieval of personal memories and therefore help to elicit narratives within the interview context. Within tourism research, photo elicitation interviews are considered particularly useful methods, as taking photographs is a deeply rooted, ritualised and institutionalised aspect of tourist experience (Cederholm 2004). As a result, photo elicitation interviews were considered a useful method for exploring the varied working lives, spaces and careers of travel bloggers. For the photo elicitation interview, participants were asked to take images which they felt captured the different elements of their working lives, spaces, or career as a travel blogger.

Within the photo elicitation interview, images selected by the researcher from the participant's own blog and social media were discussed alongside the images participants had taken themselves. The images selected by the researcher were in the form of screenshots of elements of the participant's blog or social media that the researcher wished the participant to explain in more detail. Participants were able to take and submit as many or as few images as they wished. Twenty images were always brought to photo elicitation interviews. The number of images provided by participants therefore dictated how many images the researcher selected. For example, if the participant submitted ten images, ten additional images would be selected from the participants blog or social media. The photo elicitation interview also lasted between 60 and $75 \mathrm{~min}$. Both interviews were either conducted in person or via Skype depending on the participant's availability (see Appendix 1). The quality of the responses elicited from Skype were much the same as the responses gained through in-person interviews. Both interview types facilitated the generation of high-quality data (Denscombe 2003). Both interviews were also transcribed and coded by hand by the researcher.

The research also involved a netnography. Kozinets (2010, p 60) defines netnography as a method which relies predominantly on online participant observation to 'arrive at the ethnographic understanding and representation of a cultural or communal phenomenon'. Within this research, a netnography was undertaken in order to better understand travel bloggers' virtual work and online performances. As Azariah (2012a) discusses, we must consider author-created content beyond the blog itself in order to understand how self-presentation by bloggers functions. As a result, the netnography was conducted across the participant's publicly accessible blog alongside their related Twitter, Facebook and Instagram accounts. Within netnographic 
studies, the amount and type of data captured is dependent on the nature of the phenomena of interest. Due to the large amount of content posted online by each of my participants every day, a purposive sampling strategy was used to capture the netnography data (Kozinets 2010). For the netnography, from the nineteen travel bloggers recruited for the research, one male and one female participant were selected at random from each of the hobbyist, professional and transitioning blogger categories. One additional participant had also been selected at random from the entire sample for my pilot study. Therefore, seven participants were involved in the netnographic research (see Appendix 1) and their data was captured from August 2018 to June 2019. Only data which directly related to participants travel blogging work, workspaces and/or careers was captured. The netnography data was captured via screenshotting relevant content and collating this content into a word processing document. The screenshotted data was supplemented with my own hand-written observational fieldnotes (Kozinets 2010). The netnography data and associated fieldnotes were again coded by hand, using the same coding categories as the interview data.

Discussion from both interviews alongside images from both the photo elicitation interview and the netnography inform the discussion and analysis within this paper. The image caption will detail if the images have been taken from participant's publicly accessible blog/social media during the netnography or have been shared during the photo elicitation interview solely for the purposes of the research. Through the use of a triangulation of methods, the paper provides rich descriptions and explanations which unpack the nuances and complexity of performances of digital nomadism within travel blogging work (Tracy 2010).

\section{Analysis}

In order to aid our understanding of the workplace performances of digital nomadism enacted within travel blogging work, empirical data from five participants will underpin the various themes to be explored within this analysis section. The section will open with a discussion of how the successful self-presentation of the travel blogger as an aspirational worker is hinged on digital nomadism being a core element of travel bloggers workplace performances. Next, the section will discuss how travel bloggers strategically complicate their front-stage and back-stage as a means to stage authenticity for their audience. The paper then turns to discussions of how travel bloggers must undertake performances of digital nomadism explicitly within the front-stage, in order to aid in their impression management of being a travel blogger. In particular, the paper notes how performances of digital nomadism are integral in differentiating the travel blogger as worker, as opposed to tourist. Next, it explores the role of technology in the performances of digital nomadism the travel blogger enacts across their front and back-stage. The final empirical section focuses on examples of how, through performances of digital nomadism, the travel blogger appropriates their own back-stage and the resultant impacts of this appropriation on the blogger, namely through issues of insecurity and overwork. 


\title{
7 Addressing and performing the 'digital nomad'
}

In focusing on Fig. 1, we can see how digital nomadism is presented upon the travel blog, as the facilitator and means to access a dream lifestyle. In particular, HAH situate digital nomadism as a means to escape 'monotony, stagnation and a nagging feeling that the best years of your life are passing you by' to their blogs wider audience. Digital nomadism is therefore marketed here, as a means to escape the banality of life but more specifically, the banality of work life. In focusing on STB's reflection on digital nomadism, we can also see how positioning oneself as a digital nomad ultimately fuels the aspirational component of travel blogging work. This is because the travel blogger's audience aspire to replicate a digitally nomadic lifestyle, which is free from the traditional spatial and temporal constraints of work which $\mathrm{HAH}$ detail. It is the embodiment and performance of digital nomadism that engenders the aspirational component of travel blogging work within the minds of the audience, drawing them in and as STB notes therefore helping the travel blogger to 'gain readers and followers'. The digitally nomadic element of travel blogging work is the image that travel bloggers 'sell' and is ultimately what appeals to their

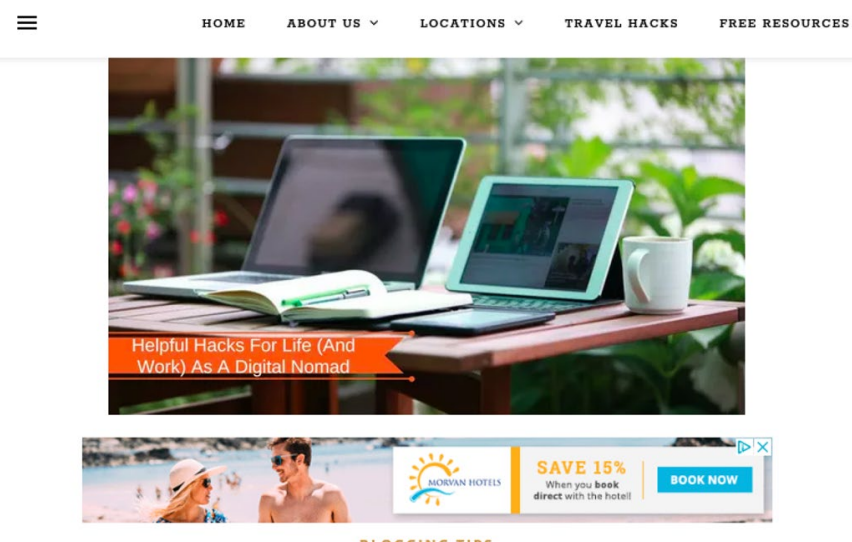

\section{Helpful Hacks For Life (And Work) As A Digital Nomad}

\author{
August 31, 2018
}

\begin{abstract}
Do you hate your job? Are you languishing in your very own fluorescent lit version of Hades? Do you yearn for adventure, excitement and challenge yet only ever get monotony, stagnation and a nagging feeling that the best years of your life are passing you by. Does your office environment feel increasingly claustrophobic and stifling. Well, the good news is that you're not alone! Yet, while many will simply carry on in their little rut, tutting and shaking their heads as they go, you will combine your love of adventure and travel with a desire to make a living on your own terms as a freelancer, by doing it alone as a digital nomad.
\end{abstract}

Fig. 1 Taken from HAH blog during netnography 'I think that's because [a digital nomad] that's what a lot of young people aspire to, so that's the image that is put out there, because that's what they aspire to...I think a lot of bloggers in that situation want to sell that lifestyle and how to do it as well, so it's sort of the perfect image to gain readers and followers I guess' STB (Interview 2) 
audience (Duffy and Kang 2019). The promotion of a digital nomad image subsequently facilitates travel blogger success, drawing in audience engagement and enabling the travel blogger to subsequently commodify this audience resource (Gamson 2011). In the case of HAH, this audience engagement and attention comes directly from content which proclaims to show others how to emulate the digitally nomadic lifestyle HAH lead. Travel bloggers therefore perform digital nomadism ostensibly within their blog, in order to position themselves and their work as exceptionally aspirational. In doing so, they appeal to an audience who wish to emulate this working lifestyle. In order for a travel blogger to be successful, digital nomadism cannot just be a pretext but must be performed as a core, inspirationally exceptional element of travel blogger's working performances and practices.

\section{Complicating the front/backstage: staged authenticity}

The proliferation and veneration of digital nomadic working practices and performances can therefore arguably be playing a role in the back-region behaviours of the worker increasingly not being hidden, but instead performed in the front-stage in full view of an audience. In the case of travel bloggers, this is resulting in predominantly backstage performances such as physically working on a laptop being adopted as a frontstage performance (as seen in Fig. 2). This is particularly pertinent, as stereotypically, travel bloggers have been under pressure to only perform certain frontstage behaviours linked to the sharing of the place of experience and to hide other behaviours such as physically travelling or working from their audience. These behaviours of working have typically been committed to the backstage region, with DFS highlighting this in his admission that "no one actually...takes photos of themselves doing that [working]'. However, we can argue that place plays a definitive role in the complication of the front-stage and back-stage within performances of digital nomadism for the travel blogger. DFS is working on his laptop, so here the 'work' element is something that is typically considered a backstage performance. However, DFS is working on his laptop on a sun-drenched cliff next to the sea. This place of work is therefore in keeping with the ideology of travel blogging as a utopian form of digitally nomadic working. The 'place' element of the workplace (i.e. it being a place of touristic experience) helps to constitute this performance of working as a viable frontstage behaviour. Building on Goffman's (1959) idea, by invoking a frontstage style in places which are in keeping with the ideology of the travel blogger as digital nomad, the individual can transform the backstage place of 'work' into the frontstage. In Fig. 2, we see a direct example of digitally nomadic working functioning to support the claim and position of the blogger as aspirational (Duffy and Kang 2019). Performances of digital nomadism as aspirational work subsequently become co-opted as a strategy of existential authenticity which ultimately functions as a mechanism to enhance the credibility of the blogger.

In focusing on how the travel blogger performs digital nomadism within their work, we can also play with MacCannell's (1999) idea of staged authenticity. Attending to travel bloggers workplace performances allows us to move beyond 


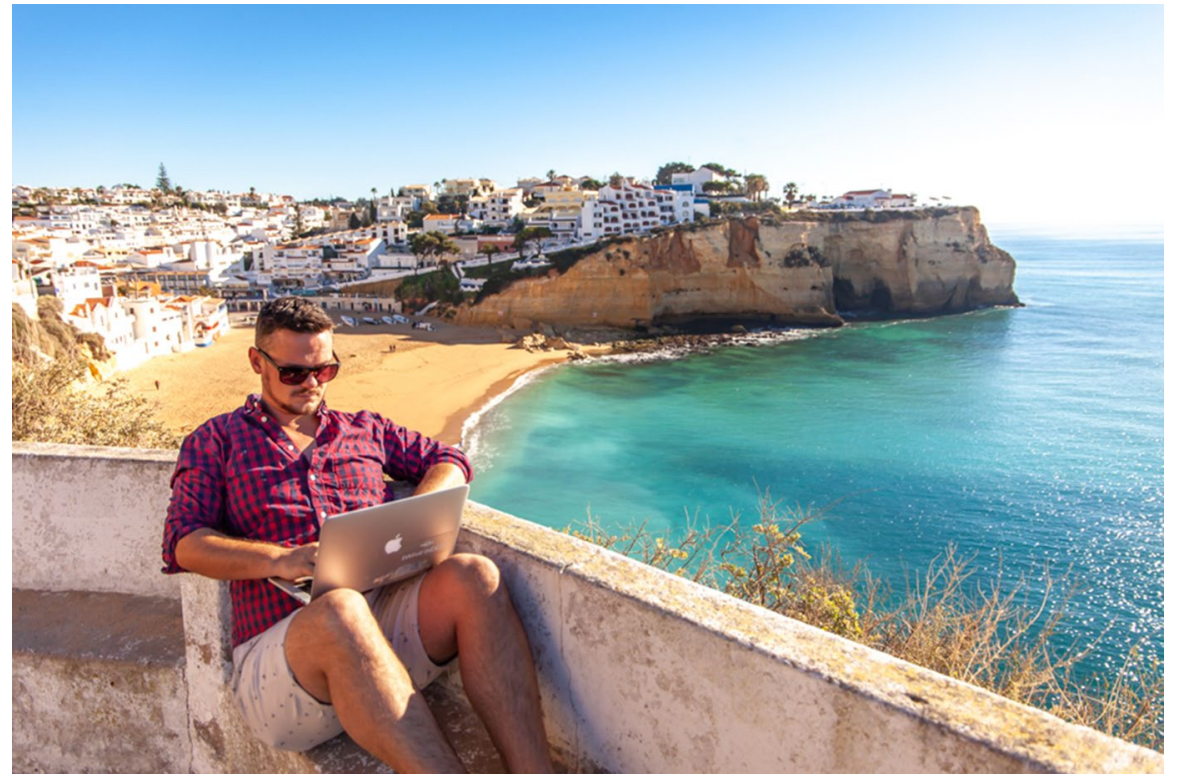

Fig. 2 Shared with researcher by DFS during photo elicitation interview 'It is somewhere I regularly go and work but it's also reflective of places that I might be working if I'm working abroad you know... that was actually from a photoshoot I had to do a couple of weeks ago for a profile piece someone was doing on me about working remotely and kind of the environments that I work in so obviously its staged because no one actually sits like that or takes photos of themselves doing that but yeah...that one is a more glammed up version of my life because I probably wouldn't normally be wearing a shirt, or looking quite so suave when I troop up there in the early morning to catch sunrise, with a coffee and do some work' DFS (Interview 2)

MacCannell's (1999) discussion, as the focus is no longer on the local staging authenticity for the tourist. Instead the focus is on the travel blogger who is staging authenticity for their audience through performances of digital nomadism. As MacCannell (1999) highlights, the front and back-regions within touristic encounters are becoming increasingly hard to distinguish. Social media and blogs are further blurring the boundaries between public and private, which is resulting in the borders between front and backstage regions becoming even more permeable. Within Fig. 2, the audience are afforded what they believe is an 'uncensored glimpse' into the 'real' backstage 'work' of being a digital nomad. Yet, DFS admits Fig. 2 is more 'glammed up version' of digital nomad working life. This more glammed up performance of digitally nomadic work is enacted as DFS knows that others will be watching. As a result, his behaviours embody a frontstage style; he attempts to look 'suave' and wears a 'shirt'. These behaviours form part of the mystification behind the travel bloggers attempted performance of an authentic digital nomad self. Marwick and boyd (2011, p 140) argue that the provision of an 'illusion' of a backstage 'allows the impression of uncensored glimpses' into the lives of individuals, for the watching audience. The result for the travel blogger performing the backstage in this way is that they create a perception of intimacy between themselves and their 
audience (Hine 2000). In staging this backstage performance of digital nomadism, the travel blogger therefore stages authenticity for their audience (Crang, 1997). In the example of DFS, we therefore see how travel bloggers utilise their backstage and front-stage performances deliberately in order to present and perform cultural meanings such as authenticity. This performance of authenticity (and therefore intimacy) is extremely important for professional travel bloggers such as DFS, as their economic income is wholly dependent on their ability to positively influence and affect their audience (Duffy and Kang 2019). As a result, professional travel bloggers (perhaps more than hobbyist or transitioning bloggers) are committed to staging performances of the self as a means to convince their audience of their authenticity.

\section{Posing and posting: Front-stage performances of digital nomadism}

For travel bloggers, there is an expectation to be at once off the beaten path experiencing the world, whilst simultaneously creating and sharing content around that experience (Azariah 2016a). We can therefore argue that the travel blog and associated social media upon which travel bloggers share their content, function as an online frontstage region upon which travel bloggers need to perform a very recognisable, polished front-region digital nomadism. Within Fig. 3, we can see how STB is performing the digital nomad role through the synonymous experiencing, capturing and sharing of her 'travel experience' with her online audience via her Instagram stories. The work behaviours involved in creating this content such as 'getting the phone out' and 'taking pictures' are obscured from the audience and therefore occur within the back-region space. This front-stage performance of digital nomadism could be understood as an example of a sign vehicle, in which the expression given is the deployment of information on the blog which decidedly highlights the travel bloggers digitally nomadic working practices. The expressions given by STB are limited solely to the curated and carefully selected performances such as the "mountains are calling highlights' from her trip. The performance of digital nomadism in this way allows travel bloggers to follow their workplace 'script', which is informed by the audience's expectations that the social performance of travel blogging should be inherently nomadic. It is this ability to be nomadic which is valued by the travel blogging audience. Therefore, working to create, curate and share content from places of touristic experiences is an integral frontstage performance in convincing the audience of the travel bloggers credibility (McWha et al. 2018).

As Goffman (1959) notes, within the frontstage, awareness of others' perceptions influences the manner and actions of the individual. In order to aid in the impression of being a certain kind of person, Goffman (1959, p 75) argues it '[is] not merely to possess the required attributes, but also to sustain the standards of conduct and appearance that one's social grouping attaches thereto.' In order for travel bloggers to perform the role of a digital nomad, frontstage behaviours of simply capturing and sharing images in destinations are not enough. Travel bloggers must perform certain frontstage photographic behaviours to ensure that their images possess the 


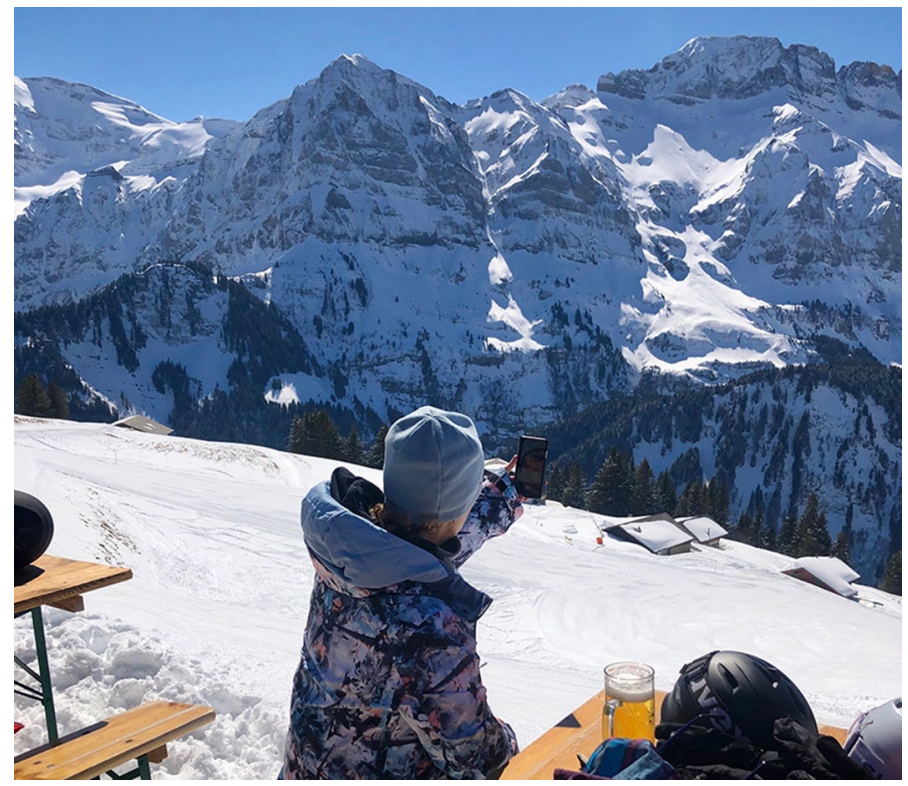

Fig. 3 Shared with researcher by STB during photo elicitation interview 'I was doing a little boomerang for Instagram... it was just on my Instagram in my stories...it's in the 'mountains are calling' highlights... ... that photo I was with my husband and two friends and I do feel sometimes that they get a bit annoyed with me because I am always getting my camera out, I'm always getting my phone out and I'm always sort of taking pictures and doing this, that' STB (Interview 2)

required attributes typical of professional, digital nomad content creation. This can inform subsequent frontstage behaviours for travel bloggers such as 'posing' or 'acting out' within the place of touristic experience, as HAH discuss. Beyond possessing the required attributes of the image, travel bloggers can further aid the impression management of being a digital nomad by ensuring their content sustains the high standards of appearance dictated by the travel blogging industry. In this instance, HAH undertake front-region behaviours such as working to get 'the right lighting' in order to attend to this. For transitioning bloggers, performing digital nomadism in the front-stage can be seen as a self-presentation strategy which helps to position them distinctly as quasi-professional 'travel bloggers' undertaking a productive form of content creation work rather than simply as hobbyists. However, if the authenticity of the travel blog stems from the presentation of the self as a hobbyist blogger, then transformation into a professional travel blogger may have ramifications for the blogs claims to authenticity (Azariah 2016b). The performance of digital nomadism decidedly in the front stage, through means such as working to perfect images, can be used as a strategic resource to reassure the audience of the claims to authenticity the blog and therefore the blogger is making (Hine 2000).

In addition to offline frontstage behaviours, front-region performances of digital nomadism must continue online through the travel bloggers constant interactions across their blog and social media. For travel bloggers, their ability to work as a digital nomad is fuelled by their means to generate revenue through audience 
engagement. For travel bloggers as digital nomads, their blog and associated social media therefore become an extended frontstage upon which the blogger must strategically present themselves. Thus, bloggers must undertake relevant frontstage behaviours as they know others are watching (Hogan 2010). Impression management therefore continues to influence how bloggers perform online. One example of a front-region behaviour undertaken by the travel blogger within their performance of digital nomadism is the visible replying to comments. This behaviour can be seen being undertaken by HAH in Fig. 4. Due to the absence of face-to-face interactions within the online sphere, features such as comment tone, likes and emojis function as 'expressions given' and ultimately play a key role in impression management (Jankala 2013). Within Fig. 4, we witness how HAH like a follower's comment and post an upbeat, friendly reply which includes two smiley emojis. This frontstage performance is undertaken because $\mathrm{HAH}$ understand that not replying can function as a virtual 'expression given off', which may influence their audience to perceive that they are inactive, inaccessible or unfriendly. This negative impression could subsequently result in the travel blogger not being offered subsequent work, which is needed for them to sustain and facilitate their digital nomad lifestyle.

\section{Offline performances, messy desktops: the staging of technology in performances of digital nomadism}

We may also consider how technology, as a material object, forms part of the particular set of performances travel bloggers undertake in order to position themselves as digital nomads. In considering Fig. 5 and 6, we can understand the different ways in which the laptop-workplace can be performed within either the front-stage or the back-stage. Within Fig. 5, we can see how, here, the MacBook is on display as the performative laptop; a shiny technology which ultimately forms part of travel blogger's performance. Following Urry and Larsen (2011), CD notes how the MacBook is staged in such a way that it becomes a 'prop', being performed within the frontstage as an integral element in the travel blogger's performance of digital nomadism. As Goffman (1959, p 75) notes where 'the front tends to be relatively well decorated, well repaired and tidy; the rear tends to be relatively unprepossessing'. This is extremely evident in the example of Fig. 6. In contrast to the polished, carefully crafted front stage laptop-workplace shown in Fig. 5. Figure 6 shows how TBT's MacBook computer desktop is messy and chaotic. For TBT, the MacBook is staged as a back-region, upon which she can undertake messy travel blogging behaviours and performances unconstrained by the expectations that dictate her frontstage blogging behaviours. Here, TBT performs backstage behaviours such as 'dump[ing] stuff... deleting...editing'. These backstage behaviours transform texts and images into the 'well decorated' features which will ultimately enter the frontstage of TBT's blog or social media posts (Orth 2016). In this situation, the laptop-workplace being in the backstage is important as it functions as a space in which TBT can undertake the physical labour vital to honing her front-region performances of digital nomadism (Goffman 1959). 


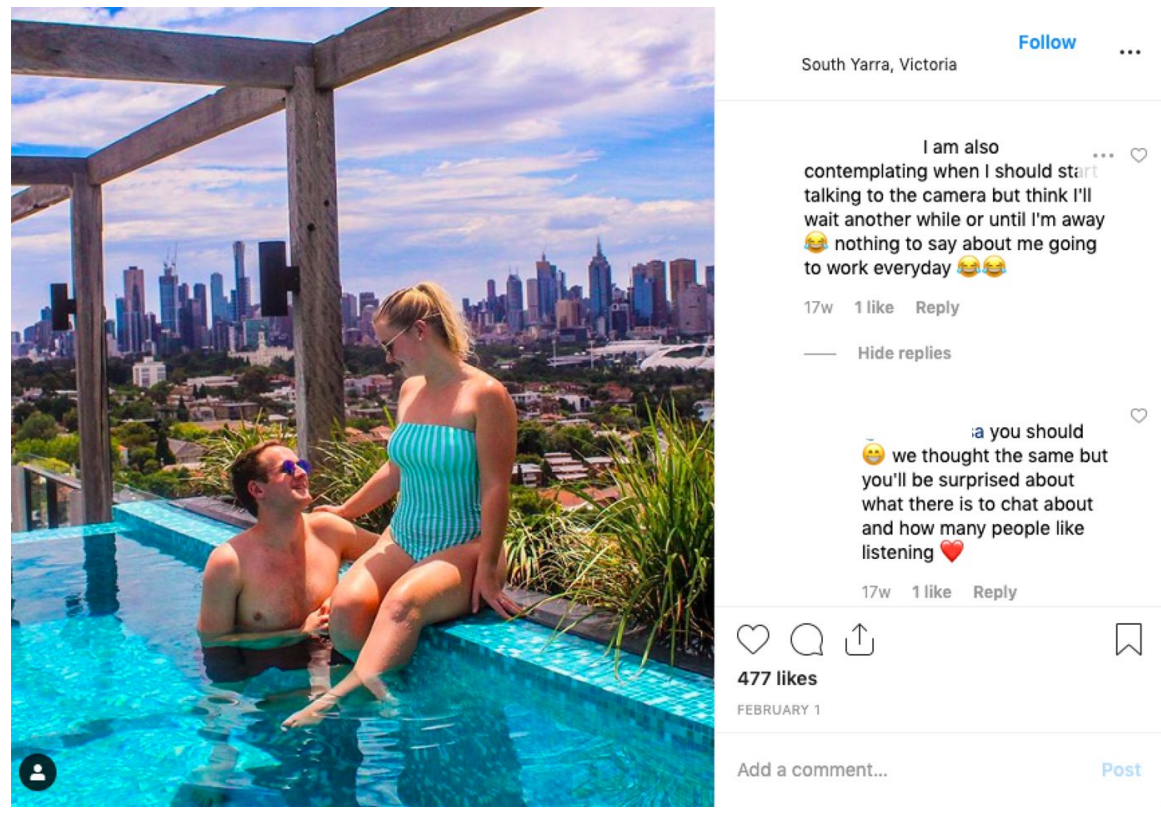

Fig. 4 Taken from HAH Instagram during netnography 'A lot of these pictures that you see posted ... they are posed, they are acted out to be like nonchalant and captured in the moment type of thing but a lot of time it takes half an hour to an hour to get the right lighting... if a cloud passes over or if the cloud clears and suddenly there is shadows you need to wait for cloud to come again.. yeah so you can tell, I guess, in person who is a travel blogger rather than just a tourist based on how they are acting around the situation when they are taking photos' HAH (Interview 2)

\title{
11 Appropriating the backstage: performances of digital nomadism, overwork and precarity
}

\begin{abstract}
'Actually a press trip is really hard work, I was on one 10 days ago and I averaged 5 hours sleep a night because we had no Wi-Fi so all the social media that we were requested to do had to be done when we got back to the hotel at night and they were 4 hours ahead...we got there late the first night, we didn't finish dinner until lam and then we had to be up again at 8 the next morning, so by the time I got back to my room, photographed my room before I'd trashed it [laughs] done all that and done that days social media it was quite late... STB (Interview 2)
\end{abstract}

In the struggle to perform digital nomadism within their work, travel bloggers can enable their audience to access their true backstage. In doing so, however, the travel blogger is allowing the front-region to appropriate the back-region within their work. This cannibalisation is particularly apparent in distinct spaces/times which blur the boundaries between the place of work and place of experience for travel bloggers. One key example of these distinct spaces/times in travel blogging work is during a press trip. Press trips are typically invite-only trips where international media players, including bloggers and influencers, are invited to a destination in exchange for their promotion 


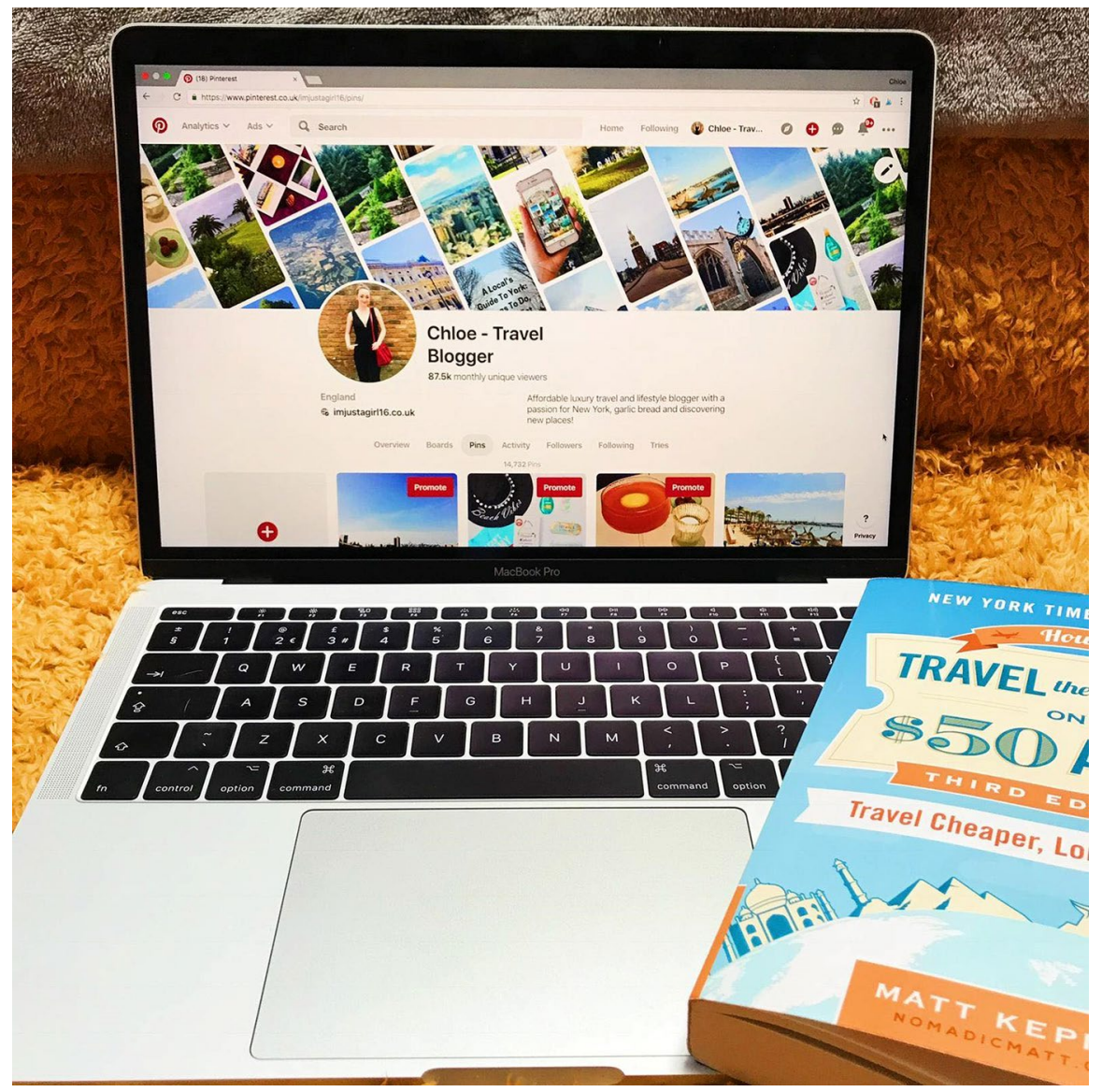

Fig. 5 Shared with researcher by CD during photo elicitation interview 'I must have taken this as a background picture for a blog post, it was probably the post I wrote about how to use Pinterest for travel bloggers...so I was using my laptop to work on Pinterest but I also captured this image to include in a post because it was relevant basically. To be honest a lot are just pictures I took for blog posts if I just wanted to show the behind the scenes... they are just blog prop pictures I guess' CD (Interview 2)

of a particular brand, activity or place during the trip. Press trips can be paid or unpaid but during the visit all elements of the itinerary i.e. accommodation, meals and activities are paid for by the brand or destination (Visit Norway 2019). Through impression management on the frontstage of their social media, the travel blogger has built up their own branded presentation of self (Van Nuenen 2015). However, during a press trip, the corporeal self of the travel blogger is present and the 'offline' back-region as it exists beyond the blog and social media is removed. Within the press trip, the travel blogger must therefore negotiate the simultaneous performance of both the online and offline self and this has implications for the front and back-regions of work. Within the press trip, the offline self of the travel blogger should be performing frontstage behaviours within the destination in order to share these experiences with their awaiting audience. 


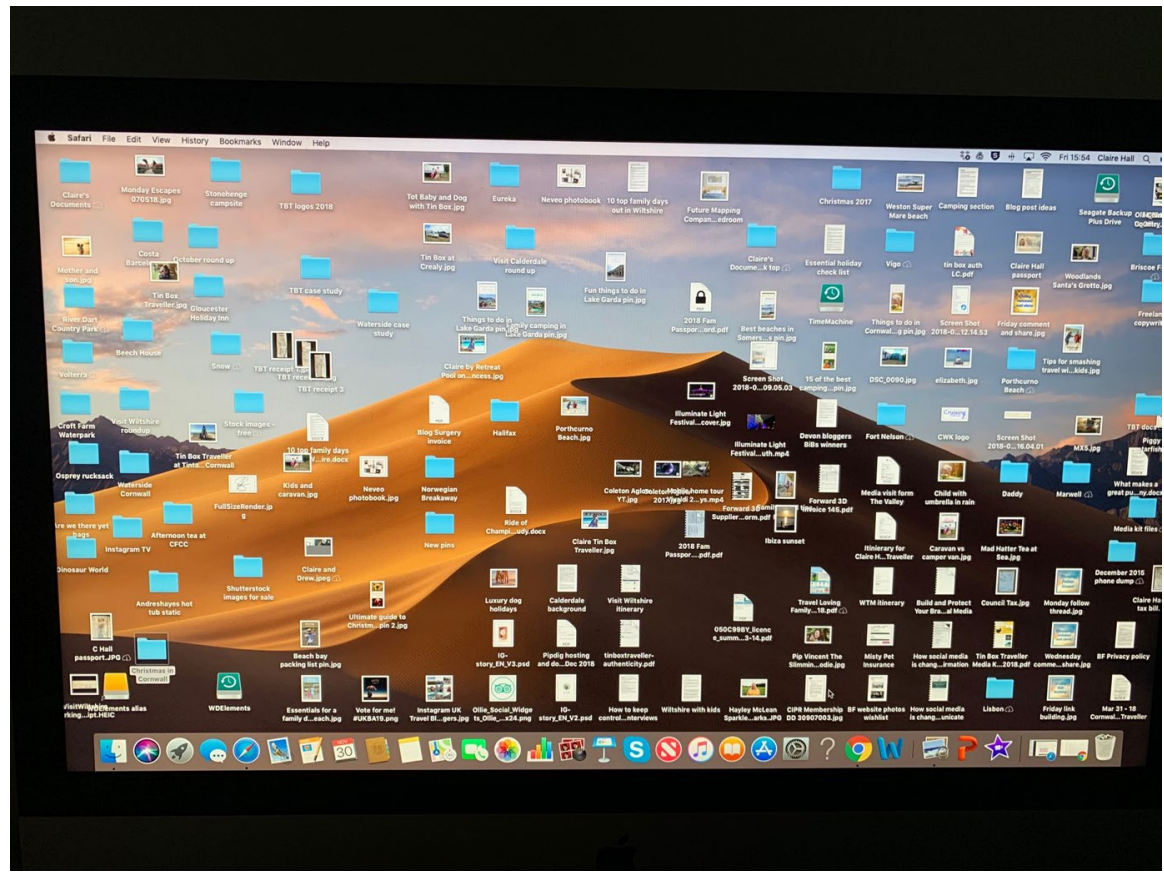

Fig. 6 Shared with researcher by TBT during photo elicitation interview 'This is where everything that I'm doing now and have done recently, it's kind of dumped... so all sorts of other documents and folders...folders of images for blog posts that I haven't written yet, folders of images of blog posts I have written... I do an awful lot of image editing and quite often I save it to the desktop and I just need to tidy it up... I feel a bit ashamed I feel as though I need a good old spring clean' TBT (Interview 2)

However, the absence of Wi-Fi in the daytime for STB during her press trip, means that for this travel blogger the frontstage of the place of experience is rendered into a backstage. The inability to share content during this time means that the blogger is free of the constraints of being on display and can therefore undertake back-region behaviours as they wish. However, as the press trip is still considered a place of 'work', the travel blogger must still follow the workplace 'script' and continuously share content.

As a result of the need to follow this workplace script, the travel blogger must sacrifice typical backstage spaces and behaviours, transforming these backstage spaces such as hotel rooms into spaces of the frontstage. This is evidenced in the example of STB. STB sacrifices backstage regions and behaviours such as relaxing in her hotel room or sleeping, in order to ensure she is creating and sharing content, as she knows both the organisers of the press trip and her audience are watching. These workplace performances are underpinned by cultural-economic logics. In part, the logic is around an issue of performing authenticity; the travel blogger wants to appear to create timely and authentic content for their audience. However, it is also in part an issue of place. For travel bloggers, the place of 'experience' and the place of 'work' blur relentlessly and where this blurring occurs back-regions cease to exist for these workers. This is seen in STB's hotel room no longer being a backstage private space, it becomes appropriated 
and part of the experience being digitally mediated and performed. The hotel room is particular interesting here as a place, because it is both a place of work (where blogging can be done via the room's Internet connection and a laptop) but also a place of relaxation (where the blogger can stop blogging in order to sleep or to rest). As a result, it is synonymously frontstage (it is photographed in order to showcase to the audience one aspect of what the destination is like) but at the same time it is backstage (a space in which the blogger can stop blogging in favour of relaxation). It is the pressure of digitally nomadic work, in the expectation of the press trip organiser that the hotel room be part of the travel blogging performance which ultimately renders this space into a front stage.

'I was burnt out from work but I was also burnt out emotionally because I didn't really have anyone to share the journey with and also because it's quite a hard industry to discuss negatively with people when you are jumping from country to country and living a dream life, as you know it does look all the time on social media... it's quite hard to then sit down and say to people I'm burnt out, I'm a bit depressed, this isn't a great time for me because you are living a great life on paper... an image that we all create online is that we're having this great time, all the time, because nobody really wants to follow you to hear you moaning about $x, y$ and $z$ ' DFS (Interview 1)

The appropriating of the backstage into a frontstage can ultimately have consequences both for the worker and the wider travel blogging industry. Focusing on the work of the American filling station manager, Goffman (1959, p 71) highlights how customers 'disregard the right of the station personnel to their own back-region' which can have a wholly negative impact on the worker. Within the example of travel blogger however, it is the workers themselves who are removing their own back-region as a result of the constant pressure on them to perform in the frontstage. This can result in the worker being constantly 'on' and having no respite from frontstage performances, which can ultimately lead to worker burnout. This is because back-regions can play a vital role in the psychological well-being of workers (Bolton 2005). Therefore, the complication of the distinction between front-stage and back-stage, inherent in travel blogger's performances of digital nomadism, is having resultant impacts in the complication of the distinction between 'work' and 'life' for the travel blogger and their audiences. This is evidenced in DFS' discussion, in which he highlights how living his digital nomad lifestyle constantly on the frontstage of social media has resulted in him suffering from burnout and depression. In increasingly performing work on display within the front stage, DFS himself has eroded the backstage in which he was able to be his uninhibited self, to 'moan' and to ultimately protect himself from the demands that being a digital nomad placed on him. As shown by DFS, these frontstage behaviours can also be extended to include the dissemination of a rhetoric of digital nomadism which correlates to freedom, autonomy and 'living a dream life'. In controlling impression management around their work in this way, travel blogger's themselves are veiling many of the real problems of their industry including precariousness and overwork (De Stefano 2016). For the audience, paying attention to these performative metaphors could result in digitally nomadic working practices being perceived as unproblematically aspirational. This could result in individuals seeking out digitally nomadic work 
without being aware of the issues of insecurity, overwork and precarity that are evident within the travel blogging industry and beyond.

\section{Conclusion}

This paper has sought to understand the self-presentation and workplace performances of travel bloggers through the lens of digital nomadism. The lens of digital nomadism has been extremely productive in enabling the paper to critically explore and engage with the themes of authenticity, place and performance inherent in travel blogging work. Drawing on empirical research with British travel bloggers, the paper contributes to current understandings and work on digital nomadism by highlighting how digital nomadism is a fundamental and guiding principle in directing travel blogger's frontand back-stage workplace performances. Building on Goffman's (1959) ideas of front and back regionalisation as a framework, the paper opened with a discussion of the role of digital nomadism in situating travel blogging as an inherently aspirational form of work. Moving to ideas of performance, the paper demonstrated how, through performances of digital nomadism, the travel blogger attempts to complicate their frontstage and back-stage, noting how this complication becomes bound up with ideas of authenticity and place. The paper then moved to explore instances in which travel bloggers ostensibly performed digital nomadism within the front stage, in order to enhance their credibility and positionality as a travel blogger. Next, the paper explored the role of technology in facilitating performances of digital nomadism across travel blogger's workplace performances. Finally, the paper discussed how, in their quest for performances of digital nomadism, the travel blogger can appropriate their own back-stage which ultimately has negative implications for the worker. On a practical note, attempting to understand travel blogger's performances and self-presentation through a digital nomad perspective can have useful repercussions in helping us to understand the increasingly dynamic and volatile online environment in which travel writing is now developing. Further lines of development could therefore build on the themes of selfpresentation and workplace performance inherent in this paper and apply them to other examples of digital nomads emerging from the rapidly evolving world of online content creation.

Acknowledgements I would like to thank Phil Crang and David Gilbert for their invaluable advice and support with the project and this paper. I would also like to thank the Economic and Social Research Council for their financial and material support.

Open Access This article is licensed under a Creative Commons Attribution 4.0 International License, which permits use, sharing, adaptation, distribution and reproduction in any medium or format, as long as you give appropriate credit to the original author(s) and the source, provide a link to the Creative Commons licence, and indicate if changes were made. The images or other third party material in this article are included in the article's Creative Commons licence, unless indicated otherwise in a credit line to the material. If material is not included in the article's Creative Commons licence and your intended use is not permitted by statutory regulation or exceeds the permitted use, you will need to obtain permission directly from the copyright holder. To view a copy of this licence, visit http://creativecommons.org/licen ses/by/4.0/. 


\section{Appendix 1}

\begin{tabular}{|c|c|c|c|c|c|c|c|c|}
\hline $\begin{array}{l}\text { Pseudo- } \\
\text { nym }\end{array}$ & Age & Ethnicity & Gender & Location & $\begin{array}{l}\text { Type of } \\
\text { Blogger }\end{array}$ & $\begin{array}{l}\text { Main } \\
\text { source of } \\
\text { income }\end{array}$ & $\begin{array}{l}\text { Interview } \\
\text { type }\end{array}$ & $\begin{array}{l}\text { Netnogra- } \\
\text { phy }\end{array}$ \\
\hline TTW & 29 & $\begin{array}{l}\text { White Brit- } \\
\text { ish }\end{array}$ & $\mathrm{F}$ & $\begin{array}{l}\text { Manches- } \\
\text { ter }\end{array}$ & Hobbyist & $\begin{array}{l}\text { Full time } \\
\text { work }\end{array}$ & In person & - \\
\hline DFS & $30-40$ & $\begin{array}{l}\text { White Brit- } \\
\text { ish }\end{array}$ & M & $\begin{array}{c}\text { Portugal } \\
\text { (previ- } \\
\text { ously } \\
\text { UK) }\end{array}$ & Professional & Blog & Skype & Yes \\
\hline BTT & $40-50$ & $\begin{array}{l}\text { White Brit- } \\
\text { ish }\end{array}$ & $\mathrm{F}$ & $\begin{array}{l}\text { Notting- } \\
\text { ham }\end{array}$ & Professional & Blog & In person & Yes \\
\hline JT & $40-50$ & $\begin{array}{l}\text { White Brit- } \\
\text { ish }\end{array}$ & $\mathrm{F}$ & Essex & $\begin{array}{l}\text { Professional } \\
\text { (profes- } \\
\text { sional } \\
\text { travel } \\
\text { writer/ } \\
\text { hobby- } \\
\text { ist travel } \\
\text { blogger) }\end{array}$ & Blog & In person & - \\
\hline $\begin{array}{l}\text { SD } \\
\text { (TTC) }\end{array}$ & DND & $\begin{array}{l}\text { White Brit- } \\
\text { ish }\end{array}$ & $\mathrm{F}$ & $\begin{array}{c}\text { Hamp- } \\
\text { shire }\end{array}$ & $\begin{array}{l}\text { Transition- } \\
\text { ing: (it } \\
\text { is not a } \\
\text { living/am } \\
\text { not self- } \\
\text { employed } \\
\text { yet but its } \\
\text { more than } \\
\text { a hobby) }\end{array}$ & DND* & In person & Yes \\
\hline HLO (L) & 34 & $\begin{array}{l}\text { White Brit- } \\
\text { ish }\end{array}$ & M & London & Professional & Blog & Skype & - \\
\hline $\mathrm{HLO}(\mathrm{Y})$ & 35 & $\begin{array}{l}\text { Black Brit- } \\
\text { ish }\end{array}$ & M & London & Professional & Blog & Skype & - \\
\hline $\mathrm{AD}$ & 25 & $\begin{array}{l}\text { White Brit- } \\
\text { ish }\end{array}$ & M & $\begin{array}{l}\text { Hertford- } \\
\text { shire }\end{array}$ & Hobbyist & $\begin{array}{l}\text { Full time } \\
\text { work }\end{array}$ & In person & Yes \\
\hline TBT & $35-44$ & $\begin{array}{l}\text { White Brit- } \\
\text { ish }\end{array}$ & $\mathrm{F}$ & Devon & Professional & Blog & Skype & - \\
\hline ICW & 25 & $\begin{array}{l}\text { White Brit- } \\
\text { ish }\end{array}$ & M & London & Hobbyist & $\begin{array}{l}\text { Full time } \\
\text { work }\end{array}$ & In person & - \\
\hline TWR & 24 & $\begin{array}{l}\text { British- } \\
\text { Indian }\end{array}$ & $\mathrm{F}$ & Berkshire & Hobbyist & $\begin{array}{l}\text { Full time } \\
\text { work }\end{array}$ & In person & - \\
\hline HIT & $50+$ & $\begin{array}{l}\text { White Brit- } \\
\text { ish }\end{array}$ & $\mathrm{F}$ & London & Hobbyist & Retired & Skype & - \\
\hline BBF & $25-35$ & $\begin{array}{l}\text { British } \\
\text { Pakistani }\end{array}$ & $\mathrm{F}$ & Kent & Hobbyist & $\begin{array}{l}\text { Full time } \\
\text { work } \\
\text { as a } \\
\text { mother }\end{array}$ & Skype & - \\
\hline MAM & 28 & $\begin{array}{l}\text { Black Brit- } \\
\text { ish }\end{array}$ & $\mathrm{F}$ & London & Hobbyist & $\begin{array}{l}\text { Full time } \\
\text { work }\end{array}$ & Skype & Yes \\
\hline
\end{tabular}




\begin{tabular}{|c|c|c|c|c|c|c|c|c|}
\hline $\begin{array}{l}\text { Pseudo- } \\
\text { nym }\end{array}$ & Age & Ethnicity & Gender & Location & $\begin{array}{l}\text { Type of } \\
\text { Blogger }\end{array}$ & $\begin{array}{l}\text { Main } \\
\text { source of } \\
\text { income }\end{array}$ & $\begin{array}{l}\text { Interview } \\
\text { type }\end{array}$ & $\begin{array}{l}\text { Netnogra- } \\
\text { phy }\end{array}$ \\
\hline LEX & $30-40$ & $\begin{array}{l}\text { White Brit- } \\
\text { ish }\end{array}$ & $\mathrm{M}$ & London & $\begin{array}{l}\text { Transition- } \\
\text { ing }\end{array}$ & $\begin{array}{l}\text { Full time } \\
\text { work }\end{array}$ & In person & - \\
\hline DG & 23 & $\begin{array}{l}\text { White Brit- } \\
\text { ish }\end{array}$ & M & Liverpool & $\begin{array}{l}\text { Transition- } \\
\text { ing }\end{array}$ & $\begin{array}{l}\text { Full time } \\
\text { work }\end{array}$ & In person & - \\
\hline STB & $50+$ & $\begin{array}{l}\text { White Brit- } \\
\text { ish }\end{array}$ & $\mathrm{F}$ & $\begin{array}{l}\text { South } \\
\text { East } \\
\text { Eng- } \\
\text { land }\end{array}$ & $\begin{array}{l}\text { Transition- } \\
\text { ing }\end{array}$ & $\mathrm{B} \log$ & Skype & - \\
\hline $\mathrm{CD}$ & 21 & $\begin{array}{l}\text { White Brit- } \\
\text { ish }\end{array}$ & $\mathrm{F}$ & York & Professional & $\mathrm{B} \log$ & Skype & Yes \\
\hline JTA & 22 & $\begin{array}{l}\text { Black } \\
\text { British/ } \\
\text { African }\end{array}$ & M & London & $\begin{array}{l}\text { Transition- } \\
\text { ing }\end{array}$ & $\begin{array}{l}\text { Full time } \\
\text { work }\end{array}$ & Skype & - \\
\hline HAH (C) & 24 & $\begin{array}{l}\text { White Brit- } \\
\text { ish }\end{array}$ & M & $\begin{array}{l}\text { Scotland } \\
\text { (now } \\
\text { Mel- } \\
\text { bourne) }\end{array}$ & $\begin{array}{l}\text { Transition- } \\
\text { ing }\end{array}$ & $\begin{array}{l}\text { Full time } \\
\text { work }\end{array}$ & Skype & Yes \\
\hline НAH (G) & 25 & $\begin{array}{l}\text { White Brit- } \\
\text { ish }\end{array}$ & $\mathrm{F}$ & $\begin{array}{c}\text { Scotland } \\
\text { (now } \\
\text { Mel- } \\
\text { bourne) }\end{array}$ & $\begin{array}{l}\text { Transition- } \\
\text { ing }\end{array}$ & $\begin{array}{c}\text { Full time } \\
\text { work }\end{array}$ & Skype & Yes \\
\hline
\end{tabular}

$D N D$ did not wish to disclose this information

\section{References}

Arsel Z, Zhao X (2011) Personal blogging, performance and the quest for fame. In: Dahl DW, Johar GV, van Osselaer SMJ (eds) Advances in consumer research, vol 38. Association for Consumer Research, Duluth

Azariah DR (2012a) Beyond the blog: the networked self of travel bloggers on Twitter. Platf J Media Commun 4(1):63-78

Azariah DR (2012b) When travel meets tourism: tracing discourse in Tony wheeler's blog. Crit Stud Media Commun 29(4):275-291

Azariah DR (2016a) Tourism, travel and blogging: a discursive analysis of online travel narratives. Routledge, London

Azariah DR (2016b) The traveller as author: examining self-presentation and discourse in the (self) published travel blog. Media Cult Soc 38(6):934-945

Blaer M, Frost W, Laing J (2020) The future of travel writing: Interactivity, personal branding and power. Tour Manag. https://doi.org/10.1016/j.tourman.2019.104009

Bolton SC (2005) Emotion management in the workplace. Houndmills, New York

Bullingham L, Vasconcelos AC (2013) The presentation of self in the online world: Goffman and the study of online identities. J Inf Sci 39(1):101-112

Cederholm EA (2004) The use of photo-elicitation in tourism research: framing the backpacker experience. Scand J Hosp Tour 4(3):225-241

Collier JJ, Collier M (1986) Visual anthropology: photography as a research method. University of New Mexico Press, Albuquerque

Crang P (1994) It's showtime: on the workplace geographies of display in a restaurant in Southeast England. Environ Plan D: Soc Sp 12(6):675-704 
Crang P (1997) Performing the tourist product. In: Rojek C, Urry J (eds) Touring cultures: transformations of travel and theory. Routledge, London, pp 137-155

Cresswell T (2006) On the move: mobility in the modern western world. Routledge, London

De Stefano V (2016) The rise of the 'just-in-time workforce': on-demand work, crowdwork and labour protection in the 'gig economy. Comp Labor Law Policy J 37(3):471-503

Denscombe M (2003) The Good Research Guide. Open University Press, Maidenhead

Duffy AM, Kang HYP (2019) Follow me I'm famous: travel bloggers' self-mediated performances of everyday exoticism. Social Media Soc. https://doi.org/10.1177/0163443719853503

Dyer R (1979) Stars. British Film Institute, London

Franklin B (2012) The future of journalism. J Stud 13(5-6):663-681

Gamson J (2011) The unwatched life is not worth living: the elevation of the ordinary in celebrity culture. PLMA 126(4):1061-1069

Goffman E (1959) The presentation of self in everyday life. Penguin, London

Hanusch F (2015) Transformative times: Australian journalists' perceptions of changes in their work. Media Int Austral 155:38-55

Hine C (2000) Virtual ethnography. Sage Publications, London

Hogan B (2010) Presentation of self in the age of social media: distinguishing performances and exhibitions online. Bull ScTechnol Soc 30(6):377-386

Jankala S (2013) Remarks from the backstage: blogging performances, blogger identity and privacy strategies. Dissertation, Aalto University

Kozinets RV (2010) Netnography-doing ethnographic research online. Sage Publishing, London

Laing JH, Crouch GI (2011) Frontier tourism: retracing mythic journeys. Ann Tour Res 38(4):1516-1534

Leary MR, Kowalski RM (1990) Impression management: a literature review and two-component model. Psychol Bull 107(1):34-47

MacCannell D (1999) The Tourist: A New Theory of the Leisure Class, 2nd edn. University of California Press, Berkeley

Marwick AE (2016) You may know me from YouTube: (micro-)celebrities in social media. In: Marshall PD, Redmond S (eds) A companion to celebrity. Wiley, Hoboken, pp 194-212

Marwick A, Boyd D (2011) To see and be seen: celebrity practice on twitter. Converg Int J Res New Media Technol 17(2):139-158

Mascheroni G (2007) Global nomads' network and mobile sociality: exploring new media uses on the move. Inf Commun Soc 10(4):527-546

McCabe S, Foster C (2006) The role and function of narrative in tourist interaction. J Tour Cult 4(3):194-215

McWha M, Frost W, Laing J (2018) Travel writers and the nature of self: essentialism, transformation and the (online) construction. Ann Tour Res 70:14-24

Meyrowitz J (1986) No sense of place: the impact of electronic media on social behaviours. Oxford University Press, Oxford

Muller A (2016) The digital nomad: buzzword or research category? Transl Soc Rev 6(3):344-348

Nash C, JarrahMH, Sutherland W, Phillips G (2018) Digital nomads beyond the buzzword: Defining digital nomadic work and use of digital technologies. In: International Conference on Information: Transforming Digital Worlds, Sheffield UK, March 25-28, pp 207-217

O’Donoghue T (2007) Planning Your qualitative research project: an introduction to interpretivist research in education. Routledge, Abingdon

Orth O (2016) Presentation of Selfie: A Modern Understanding of Goffman's Self on Instagram. Dissertation, Towson University

Paris CM (2012) Flashpacking: a discussion of independent travel in a digital world. In: formation and communication technologies in tourism 2012. Helsingborg Sweden, January 24-27, pp 191-202

Picone I (2015) Impression management in social media. Int Encycl Dig Commun Soc. https://doi. org/10.1002/9781118767771.wbiedcs071

Pirolli B (2017) Travel journalists and professional identity: ideology and evolution in an online era. J Pract 11(6):740-759

Puhringer S, Taylor A (2008) A practitioner's report on blogs as potential source for destination marketing intelligence. J Vacat Mark 14(2):177-187

Rosenkranz T (2016) Becoming entrepreneurial: crisis, ethics and marketization in the field of travel journalism. Poetics 54:54-65 
Rosenkranz T (2019) From contract to speculation: new relations of work and production in freelance travel journalism. Work Employ Soc 33(4):613-630

Schlagwein D (2017) Escaping the rat race': Different Orders of Worth in Digital nomading. In: International Workshop on the Changing Nature of Work, Seoul South Korea, 10th December

Sweetser KD, Keshelashvili A (2005) Examining the new influencers: a self-presentation study of A-list blogs. J Mass Commun Q 82(4):1-22

Tracy (2010) Qualitative quality: eight 'Big-Tent' criteria for excellent qualitative research. Qual Inquiry 16(10):837-851

Urry J, Larsen J (2011) The Tourist Gaze 3.0. Sage Publications, London

Van Nuenen T (2015) Here am: authenticity and self-branding on travel blogs. Tour Stud 16(2):192-212

VisitNorway (2019) Media assistance. https://www.visitnorway.com/media/assistance/. Accessed 11 July 2019

Wang N (1999) Rethinking authenticity in the tourism experience. Ann Tour Res 26(2):349-370

Publisher's Note Springer Nature remains neutral with regard to jurisdictional claims in published maps and institutional affiliations. 